\title{
Havachoobe (Onosma dichroanthum Boiss) Root Extract Decreases the Hepatitis B Virus Surface Antigen Secretion in the PLC/PRF/5 Cell Line
}

\author{
Alireza Mohebbi ${ }^{a}$ b, c Fahimeh Azadi ${ }^{a}$ Mohammad Mostakhdem Hashemi ${ }^{a}$ \\ Fatemeh Sana Askari ${ }^{a}$ Nazanin Razzaghi ${ }^{d}$ \\ a Student Research Committee, School of Medicine, Golestan University of Medical Sciences, Gorgan, Iran; ${ }^{b}$ Stem \\ Cell Research Center, Golestan University of Medical Sciences, Gorgan, Iran; 'Department of Microbiology, Golestan \\ University of Medical Sciences, Gorgan, Iran; 'Laboratory Sciences Research Center, School of Medicine, Golestan \\ University of Medical Sciences, Gorgan, Iran
}

\section{Keywords}

Havachoobe · Hepatitis B virus · Hepatitis B virus surface antigen · Onosma dichroanthum Boiss · Anti-hepatitis B virus surface antigen $\cdot$ Natural product $\cdot$ Herbal medicine

\begin{abstract}
Background: Many efforts are currently focused on functional treatment of the hepatitis B virus (HBV). This can be done by suppressing the secretion of HBV surface antigen (HBsAg). Scientific communities are very interested in natural products in that respect. Objective: Use of root extract of Havachoobe (Onosma dichroanthum Boiss)), a Northern Iranian native medical herb, for assessment of its anti-HBsAg secretion activity. Methods: Havachoobe had been bought at a nearby apothecary store. Plant root extract was obtained using a hydroalcoholic process. Cytotoxic activity of the extract was examined on PLC/PRF/5 cells using MTT assay. ELI$\mathrm{SA}$ has been used to measure HBsAg in the treated cell line supernatants. In addition, real-time PCR analysis was performed to evaluate the expression of HBsAg before and after treatment of Onosma in vitro. Results: The results showed very low root extract cytotoxicity at concentrations under 8 $\mu \mathrm{g} / \mathrm{mL}$. Tissue culture infectious dose 50 was obtained at $63.78 \mu \mathrm{g} / \mathrm{mL}$. In a dose-dependent and time-dependent
\end{abstract}

manner, a significantly reduced HBsAg secretion was observed at a concentration of $8 \mathrm{ppm}$ at $12 \mathrm{~h}$ post-treatment. The real-time PCR result showed relative decreased $\mathrm{HBsAg}$ expression at all doses at $12 \mathrm{~h}$ post-treatment time. Discussion: In this study, we first reported anti-HBsAg activity on an Iranian herbal medicine. Havachoobe root extract was shown to be able to inhibit HBsAg in a dose-dependent and time-dependent manner. We find the extract exerts its inhibitory effect of $\mathrm{HBsAg}$ by targeting transcription of $\mathrm{HBsAg}$.

ㄷ) 2020 S. Karger AG, Basel

\section{Introduction}

A group of highly species-specific viruses forms the family Hepadnaviridae. One member of this family is the human hepatitis B virus (HBV), which causes chronic hepatitis B and hence cirrhosis and hepatocellular carcinoma [1-3]. There are $>250$ million chronically infected people worldwide and 600,000 deaths every year from organ failure associated with HBV [4]. Several FDA-approved nucleos $(\mathrm{t})$ ide analogs are recommended to reduce the risk of HBV-induced hepatocellular carcinoma, including lamivudine, adefovir, entecavir, telbivudine, and tenofovir, which suppress or reduce viral replication [5]. karger@karger.com

www.karger.com/int

Karger

(C) 2020 S. Karger AG, Basel 
Long-term treatment with nucleos(t)ide analogs has chances of drug-resistant viral quasispecies arising [6]. In fact, a functional treatment for $\mathrm{HBV}$ is to inhibit secretion of the HBV surface antigen ( $\mathrm{HBsAg}$ ) from infected cells [4]. Therefore, innovative therapeutic advances with anti-HBV practices can provide in-depth insight into the mechanism of viral pathogenesis and less toxic treatment. Being great sources of novel biomolecules, herbs and their metabolites has promising treatment options. A considerable number of drugs are now being formulated from herbs that are involved in treating various diseases [7-9]. The genus Onosma L. (Boraginaceae) includes numerous species distributed in Asia, Eurasia, the Mediterranean, and Europe $[10,11]$ and comprises approximately 150 known species in Asia, including 29 in China, 95 in Turkey, 8 in Pakistan [10], and 39 in Iran $[10,12]$.

Iran with a diverse climate and a wide variety of medicinal herbs could be a source of active compound isolation that might be effective against viruses [13]. Havachoobe (Onosma dichroanthum Boiss) is a unique medical herb in the province of Mazandaran, Iran. Havachoobe's root extracts are anti-inflammatory and are used to treat and heal burns wounds [14]. Moreover, certain members of this genus are also used for treating diseases such as shortness of breath, tonsillitis, stomach ulcer, rheumatism, cardiovascular disease, and renal hemorrhoids, and hoarseness. In addition to their therapeutic properties, red dye of the roots is also used as a colorant in the textile and food industry. The major constituents of Havachoobe root are phenol, anthocyanin, and flavonoids [15]. Ellagic acid was among the flavonoids that have anti-HBV activity [16]. Oenanthe javanica plant flavones have demonstrated anti-HBV activity by inhibiting HBsAg at nontoxic concentrations in $\mathrm{HBV}$-infected ducks and cell line HepG2.2.15 [17].

As Havachoobe's main compartment is stated to consist of flavonoids $[14,15,18]$, we decided to experiment its anti-HBV activity. The purpose of this study was thus to investigate the effect of Havachoobe root extract on HBsAg secretion in the cell line PLC/PRF/5. The results showed that HBsAg secretion at nontoxic plant extract concentrations was significantly reduced.

\section{Material and Methods}

\section{Plant Material}

Havachoobe was purchased from a local apothecary shop in Gorgan, Iran. The hydroalcoholic plant extract was prepared based on the maceration method after taxonomic identification of the plant. To this end, plant materials were left to be well dried in day- light. An electric blender was used to thoroughly powder the dried plant and $100 \mathrm{~g}$ of the material was put in a $1,000 \mathrm{~mL}$ beaker. 500 $\mathrm{mL}$ of alcohol/distilled water solution (with the ratios of 30 and $70 \%$ respectively) was added to the beaker and mixed properly. After $72 \mathrm{~h}$, the solvent was separated and the remaining solution was filtered by using the Whatman filter paper $(0.2 \mu \mathrm{m})$. The yielded crude extract was then concentrated using a rotary evaporator. The final plant extract was used to make the serial concentration used in this study.

\section{Sample Preparation}

The residues of the final raw extract were suspended in dimethyl sulfoxide/medium (1:9), and dilutions of $1 \mathrm{ppm}(1 \mu \mathrm{g} / \mathrm{mL}), 2,4$, $8,16,32,64$, and $128 \mathrm{ppm}$ were obtained. All of these serial concentrations were again centrifuged at $10,000 \mathrm{~g}$ for $5 \mathrm{~min}$ to eliminate any probable undissolved fractions.

\section{Cell Culture of PLC/PRF/5}

$\mathrm{PLC} / \mathrm{PRF} / 5$ has been provided from our group's previous study [19]. A complete medium containing Dulbecco's Modified Eagle Medium (Gibco, Waltham, MA, USA) supplemented with $10 \%$ Fetal Bovine Serum (Gibco, Waltham, MA, USA) and 1\% Pen/ Strep (Gibco, Waltham, MA, USA) antibiotics was prepared for cell culture. A vial of cell line was melted and propagated on T-75 flasks and incubated at $37^{\circ} \mathrm{C}$ with $5 \% \mathrm{CO}_{2}$ and $10 \%$ humidity. After reaching a confluency of $\geq 90 \%$, the cells were harvested and seeded into 96 -well plates supplemented with complete medium for cell cytotoxicity assay.

\section{Cell Viability and Cytotoxicity Assay}

$\mathrm{PLC} / \mathrm{PRF} / 5$ cells were seeded with either complete medium or medium containing honeybee crowd extracts. Briefly, 8,00010,000 cells/well were seeded in a 96-well plate and incubated for $12 \mathrm{~h}$. Subsequently, supernatants were removed and replaced with either fresh complete medium or extracts. Cell viability was assessed with MTT assay (Sigma, St. Louis, MO, USA) for 12, 48, and $72 \mathrm{~h}$ post-treatment. Wells were washed with PBS (Gibco, Waltham, MA, USA) after each time point, and MTT was added (20 $\mu \mathrm{L} /$ well). Once MTT was reduced and violet crystals formed, formazan crystals were dissolved by adding dimethyl sulfoxide (100 $\mu \mathrm{L} /$ well). Plates were read with ELISA reader (BioTeck, Lionheart Technologies, Inc., Winooski, VT, USA) at $570 \mathrm{~nm}$. Each test was measured in triplicate.

\section{Investigation of HBsAg Secretion}

For the investigation of inhibition of HBsAg secretion, 8,00010,000 cells were seeded in duplicate into 96 -well plates. Twelve hours later cells were washed with PBS and replaced with either the complete medium or medium containing the root extract of the plant at nontoxic concentrations. After 12,48 , and $72 \mathrm{~h}$ post-treatment, supernatants were collected and stored at $-20^{\circ} \mathrm{C}$ for $\mathrm{HBsAg}$ ELISA assay. HBsAg Sandwich ELISA kit (PadTanDanesh Co., Tehran, Iran) was used to detect HBsAg in the supernatant according to the manufacturing protocol. The plates were read at $450 \mathrm{~nm}$ with the ELISA reader (Bio Teck, Lionheart Technologies, Inc., Winooski, VT, USA). The cutoff value was 0.2 , and the result was determined using the following formula:

$$
S / C o=\frac{\text { Sample OD }}{\text { Cut }- \text { off value }} .
$$




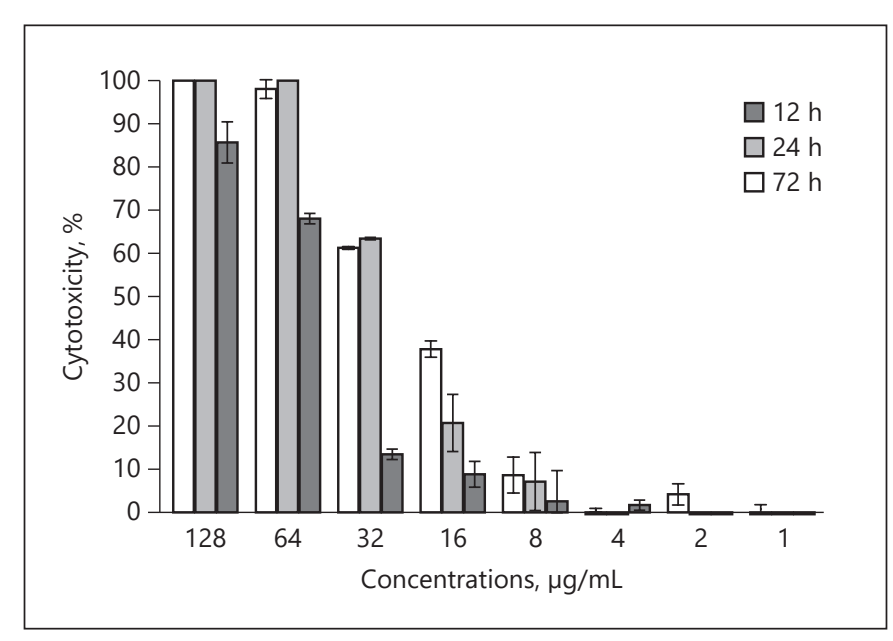

Fig. 1. Cytotoxicity of different concentrations of Havachoobe in the PLC/PRF/5 cell line containing integrated HBV genome at 12, 24 , and $72 \mathrm{~h}$ post-treatment. No substantial cytotoxicity to concentrations below 8 ppm was observed.

S/Co values $>1$ were considered positive. ODs for each test were also used to evaluate the levels of HBsAg reduction in the supernatant of the treated cells.

\section{Real-Time PCR Analysis of HBsAg Expression}

An initial 96-well plate with 8,000-10,000 PLC/PRF/5 cells/ well was seeded and incubated for $12 \mathrm{~h}$. Wells were washed and refilled with fresh complete medium as control or Havachoobe root extract at nontoxic concentrations. For the analysis of HBsAg expression, RNA was extracted from both treated and untreated cells with Trizol solution (DNAbiotech Co., Tehran, Iran) at 12, 48 , and 72 h post-treatment. cDNA was synthesized with the RevertAid First Strand cDNA Synthesis Kit (Thermo Scientific ${ }^{\mathrm{TM}}$, Waltham, MA, USA) and according to its protocol. For each sample, 600 ng of RNA was used for cDNA synthesis. The cDNA synthesis was further confirmed by the amplification of the GAPDH gene [20]. Expression of the HBsAg gene was evaluated in controlled and treated cells with SYBR Green qPCR Master Mix Kit (Yekta-Tajhiz Inc., Tehran, Iran) and a specific primer pair (forward: TGTTCAGTGGTTCGTAGGGC and reverse: ACAGCGGCATAAAGGGCATC). Thermal cycling was as follows: a 2 min $94^{\circ} \mathrm{C}$ followed by 35 cycles of $94^{\circ} \mathrm{C}$ for $30 \mathrm{~s}, 58^{\circ} \mathrm{C}$ for $30 \mathrm{~s}$, and $72^{\circ} \mathrm{C}$ for $20 \mathrm{~s}$. Each test was repeated 3 times. A series of five 1:10 diluted untreated RNA samples were used to determine the RT-PCR efficacy. Fold change of HBsAg expression levels was estimated by using the method of $2^{-\Delta \mathrm{Ct}}$ in control and treated cells.

\section{Statistical Analyses}

Statistical analyses were carried out with GraphPad Prism 7. Two-way ANOVA was a statistic for analysis of differences in cytotoxicity of the extract and HBsAg expression at 12,48 , and $72 \mathrm{~h}$ post-treatment of different concentrations of plant extracts. Graphs were produced using MS Excel 2016 and GraphPad Prism 7.

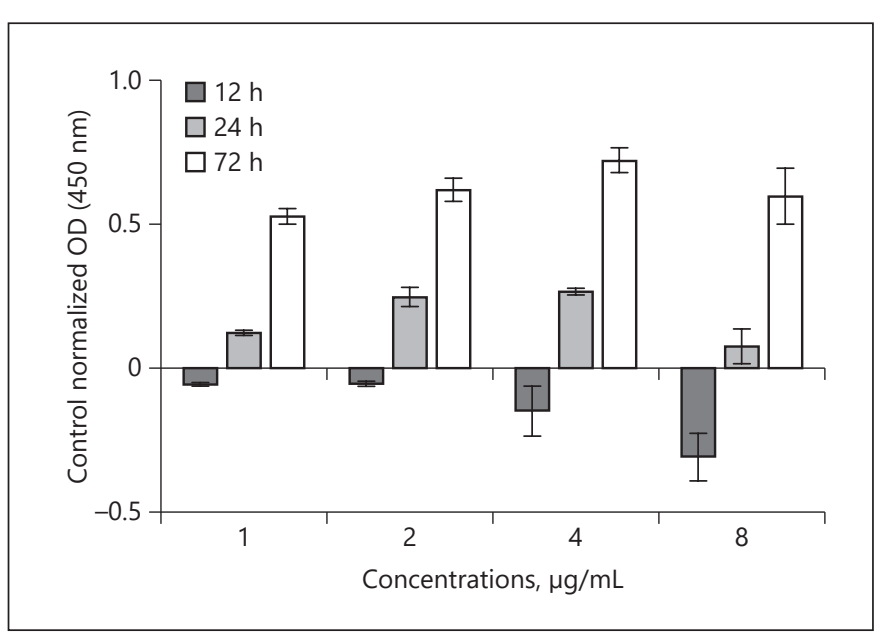

Fig. 2. Qualitative ELISA assay results. It shows a significant reduction in HBsAg levels at $12 \mathrm{~h}$ post-treatment. There were no significant differences between 48 and $72 \mathrm{~h}$ post-treatment levels of HBsAg. At $12 \mathrm{~h}$, there was a significant reduction in HBsAg at 8 ppm compared to 1,2 , and 4 ppm ( $p$ value $<0.001)$. HBsAg, hepatitis $\mathrm{B}$ virus surface antigen.

\section{Results}

\section{Onosma Tissue Culture Infectious Dose 50}

As a result of cytotoxicity assay, tissue culture infectious dose 50 (TCID50) was obtained as $63.78 \mu \mathrm{g} / \mathrm{mL}$ at $12 \mathrm{~h}$ post-treatment. No significant cytotoxicity was observed at $1,2,4$, and $8 \mathrm{ppm}$ concentrations at $12 \mathrm{~h}$ post-treatment of $\mathrm{PLC} / \mathrm{PRF} / 5$. While higher concentrations of 64 and 128 ppm had 83 and $86 \%$ cytotoxicity, respectively (Fig. 1).

At this point, 4 concentrations $(1,2,4$, and $8 \mathrm{ppm})$ with no cytotoxicity were selected for the investigation of $\mathrm{HBsAg}$ secretion in the PLC/PRF/5 cell line supernatant using the ELISA assay. As shown in Figure 2, reduced concentrations of HBsAg were observed in a time-dependent manner at the extract's $8 \mathrm{ppm}$. However, the HBsAg level restored after 48 and $72 \mathrm{~h}$ of post-treatment.

We also asked whether the extract had anti-HBsAg activity at the level of gene expression. Significant differences in HBsAg expression levels were observed at higher concentrations of the extract. Figure 3 shows the cycle threshold changes in HBsAg expression in treated and untreated control cells. As the resulted $\Delta$ CTs were below 1 , data values were transformed $(1 / \Delta \mathrm{CT})$ to obtain foldchange of reduction of HBsAg. Consistent with the ELISA result, after $12 \mathrm{~h}$ post-treatment we observed significantly reduced HBsAg expression level (32.22 fold) at $8 \mathrm{ppm}$. In addition, higher levels of HBsAg expression were observed at 48 and $72 \mathrm{~h}$ post-treatment. 


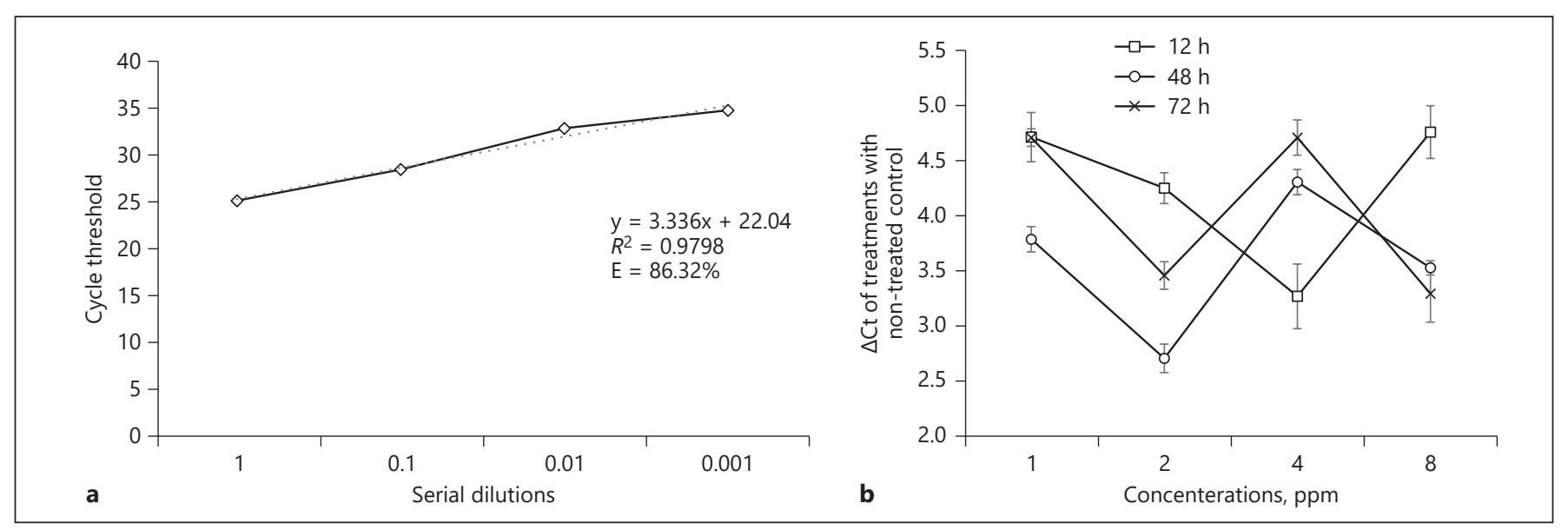

Fig. 3. a shows linearity of serially diluted RNA extracted from non-treated PLC/PRF/5 cell line. As a result, the efficiency of the performed real-time PCR was $86.32 \%$. b shows the CT variation between treated and untreated groups in HBsAg expression. At any time point, no noticeable fold-change was observed at expression levels of HBsAg at 1 ppm concentration. Overall, reduced levels of HBsAg were observed in all 4 concentrations of Havachoobe. HBsAg, hepatitis B virus surface antigen.

\section{Discussion}

A functional cure for chronic hepatitis $B$ is known to be achieved by suppressing HBsAg secretion [4]. There are several significant approaches to inhibition of HBsAg secretion, including nucleic acid polymers [21] and gene silencing by small interference RNAs [22]. Further research in these ways is still ongoing. Nature, meanwhile, is a vast source of substances for the discovery of active products acting against human pathogens $[23,24]$ like viruses.

In the present study, the inhibitory effect of Havachoobe root extract on HBsAg secretion in PLC/PRF/5 cell line was assessed. It has been recorded that the primary liver carcinoma-derived cell line (PLC/PRF/5) contains the integrated form of HBV adw subtype sequence [25, 26]. Therefore, this cell line contains last fragment of the HBV genome, producing and secreting HBsAg but no other known viral protein [27]. This makes this cell line suitable for studying the effects of novel compounds on HBsAg expression and secretion. Since cells do not produce infectious virion particles it is also safe to handle.

Nowadays, a large number of drugs are produced from plants that are active against various diseases [7-9]. Onosma species is mainly distributed in Asia, Eurasia, the Mediterranean, and Europe $[10,11]$ and contains about 230 species $[10,28]$. In this study, the cytotoxic activity of Havachoobe root extract was investigated using MTT assay on PLC/PRF/5 cell line. The results showed a TCID50 of $63.78 \mu \mathrm{g} / \mathrm{mL}$ at $12 \mathrm{~h}$ post-treatment. No significant toxicity was observed at any dose at $12 \mathrm{~h}$ post-treatment. Low- er doses of the extract $(1,2,4$, and $8 \mathrm{ppm})$ had no toxicity in the cell line at 12,48 , and $72 \mathrm{~h}$ post-treatment. These concentrations were selected for the HBsAg secretion and expression investigation in the PLC/PRF/5 cell line.

The HBsAg secretion was quantified in the supernatant of the treated cell line. The result showed a significant dose-dependent and time-dependent reduction in HB$\mathrm{sAg}$ at $12 \mathrm{~h}$ post-treatment. Nevertheless, after $48 \mathrm{~h}$, the HBsAg level was restored, and it increased at $72 \mathrm{~h}$ after treatment. This could be due to the half-life of the extract and the continued expression and production of the antigen in the integrated form of the HBsAg gene. However, compared to other concentrations, the production of HB$\mathrm{sAg}$ at $8 \mathrm{ppm}$ of the extract was lower at all 3 post-treatment time points.

In order to assess whether the reduced HBsAg is due to suppression of the HBsAg gene, a real-time PCR has been performed to amplify the regions encoding the $\mathrm{HBsAg}$ gene in the PLC/PRF/5 cells. The results showed a 32.22-fold decrease in HBsAg expression at $8 \mathrm{ppm}$ of the extract at $12 \mathrm{~h}$ post-treatment. Consistent with the ELISA results, HBsAg expression was increased at 48 and $72 \mathrm{~h}$ post-treatment. There were also some controversies, such as a significant reduction in HBsAg expression at 4 ppm at $72 \mathrm{~h}$ post-treatment, which could be a result of PCR efficiency (86.32\%). Nevertheless, the results suggests that the root extract of Havachoobe targets HBsAg secretion at transcriptional process. Further information could be obtained through analysis of the role of Havachoobe root main components in the same experiment. 


\section{Conclusion}

In the present study, we showed anti-HBV activity of Havachoobe, an Iranian herbal medicine. The root extract of the plant had low cytotoxicity at its inhibitory dose. The result of qPCR showed that the extract targets expression of HBsAg in the PLC/PRF/5 cell line.

\section{Statement of Ethics}

Ethical approval was not required because no human or animal subjects are included in the study.

\section{Conflict of Interest Statement}

The authors have no conflicts of interest to disclose.

\section{Funding Sources}

This article was derived from a grant in the field of virology and fully supported by Golestan University of Medical Sciences, Gorgan, Iran.

\section{Author Contributions}

All the mentioned authors are agreed to be accountable for all aspects of the work in ensuring that questions related to the accuracy or integrity of any part of the work are appropriately investigated and resolved. Each author has contributed to any of the parts of the study, including acquisition, analysis, interpretation of data, drafting the work or revising it critically for important intellectual content, and final approval of the version to be published.

\section{References}

1 Zoulim F, Locarnini S. Hepatitis B virus resistance to nucleos(t)ide analogues. Gastroenterology. 2009;137(5):1593-608.e1.2.

2 Dandri M, Locarnini S. New insight in the pathobiology of hepatitis B virus infection. Gut. 2012;61(Suppl 1):i6.

3 Mohebbi A, Mohammadi S, Memarian A. Prediction of HBF-0259 interactions with hepatitis $B$ virus receptors and surface antigen secretory factors. Virusdisease. 2016;27(3): 234.

4 Mohebbi A, Lorestani N, Tahamtan A, Kargar NL, Tabarraei A. An overview of hepatitis B virus surface antigen secretion inhibitors. Front Microbiol. 2018;9(April):1-9.

5 Lim Y-S. Management of antiviral resistance in chronic hepatitis B. Gut Liver. 2017;11(2): 189-95.

6 Gish R, Jia JD, Locarnini S, Zoulim F. Selection of chronic hepatitis $B$ therapy with high barrier to resistance. Lancet Infect Dis. 2012; 12(4):341-53.

7 Ali A, Hussain F, Shahid M. Investigation of the wound healing potential of Onosma hispidum root extract in rabbit models. Prog Nutr. 2015;17(3):245-9.

8 Asadi SY, Parsaei P, Karimi M, Ezzati S, Zamiri A, Mohammadizadeh F, et al. Effect of green tea (Camellia sinensis) extract on healing process of surgical wounds in rat. Int $J$ Surg. 2013;11(4):332-7.

9 Khan AA, Kumar V, Singh BK, Singh R. Evaluation of wound healing property of Terminalia catappa on excision wound models in wistar rats. Drug Res. 2014;64(5):225-8.

10 Kumar N, Kumar R, Kishore K, Onosma L. Onosma L.: a review of phytochemistry and ethnopharmacology. Pharmacogn Rev. 2013; 7(14):140-51.

11 Kandemir A, Türkmen Z. Türkiye'nin doğu anadolu bölgesinden (Boraginaceae) yeni bir onosma (Boraginaceae) Türü. Turk J Bot. 2010;34(4):277-82.

12 Ahmad Reza M, Masoud S, Zahra N, Younes A, Valeyollah M. Inter-simple sequence repeats (ISSR) and morphological diversity in Onosma L. (Boraginaceae) species in Iran. Afr J Biotechnol. 2011;10(53):10831-8.

13 Moradi M-T, Rafieian-Kopaei M, Karimi A. A review study on the effect of Iranian herbal medicines against in vitro replication of herpes simplex virus. Avicenna J Phytomed. 2016;6(5): 506-15.

14 Moghaddam PZ, Zolfaghari MR, Ghaemi EA, Mazandarani M, Mansourian AR, Taheri SA. Negative performance of root extract of Onosma dichroanthum Boiss. on the burn wound healing in an animal model. Arch Clin Microbiol. 2011;2(5).

15 Mazandarani M. Effects of solvent type on phenolics and flavonoids content and antioxidant activities in Onosma dichroanthum Boiss. J Med Plants Res. 2012;6(28).

16 Shin MS, Kang EH, Lee YI. A flavonoid from medicinal plants blocks hepatitis B virus-e antigen secretion in HBV-infected hepatocytes. Antiviral Res. 2005;67(3):163-8.

17 Wang WN, Yang XB, Liu HZ, Huang ZM, Wu GX. Effect of Oenanthe javanica flavone on human and duck hepatitis B virus infection. Acta Pharmacol Sin. 2005;26(5):587-92.

18 Mazandarani M, Moghaddam PZ, Baiat H, Zolfaghari MR, Ghaemi EA, Hemati H. Antioxidant activity, phenol, flavonoid and anthocyanin contents in various extracts of Onosma dichroanthum Boiss. In north of Iran. Iran J Plant Physiol. 2011;1(3):169-76.

19 Sheikh M, Eshraghi HR, Khoshnia M, Mazandarani M, Moradi A. Cytotoxic effect of Capparis spinosa $\mathrm{L}$. on the $\mathrm{PLC} / \mathrm{PRF} / 5$ human hepatocellular carcinoma cell line. Med Lab J. 2017;11(4)):9-12.
20 Javid N, Mohebbi A, Eskandarian S, Tahamtan A, Askari FS, Moradi A, et al. Detection of human herpes virus type- 6 in patients undergoing hemodialysis. Future Virol. 2018;13(4):237-43.

21 Vaillant A. Nucleic acid polymers: broad spectrum antiviral activity, antiviral mechanisms and optimization for the treatment of hepatitis $B$ and hepatitis D infection. Antiviral Res. 2016; 133:32-40.

22 Schluep T, Lickliter J, Hamilton J, Lewis DL, Lai CL, Lau JY, et al. Safety, tolerability, and pharmacokinetics of ARC-520 injection, an RNA interference-based therapeutic for the treatment of chronic hepatitis B virus infection, in healthy volunteers. Clin Pharmacol Drug Dev. 2017;6(4):350.

23 Saleem M. Natural products as antimicrobial agents: an update. Novel Antimicrob Agents Strategies. 2014;219-94.

24 Lin L-T, Hsu W-C, Lin C-C. Antiviral natural products and herbal medicines. J Tradit Complement Med. 2014;4(1):24-35.

25 Ziemer M, Garcia P, Shaul Y, Rutter WJ. Sequence of hepatitis B virus DNA incorporated into the genome of a human hepatoma cell line. J Virol. 1985;53(3):885.

26 Koch S, Freytag von Loringhoven A, Kahmann R, Hofschneider PH, Koshy R. The genetic organization of integrated hepatitis $\mathrm{B}$ virus DNA in the human hepatoma cell line PLC/PRF/5. Nucleic Acids Res. 1984;12(17):6871.

27 Chakraborty PR, Ruiz-opazo N, Shouval D, Shafritz DA. Identification of integrated hepatitis B virus DNA and expression of viral RNA in an HBsAg-producing human hepatocellular carcinoma cell line. Nature. 1980;286(5772): 531.

28 Binzet R, Kandemir I, Orcan N. Palynological classification of Onosma L. (Boraginaceae) species from east Mediterranean region in Turkey. Acta Bot Croat. 2010;69(2):259-74. 